\title{
Water retention capacity in Arenosols and Ferralsols in a semiarid area in the state of Bahia, Brazil
}

\section{ROBERTO DA B.V. PARAHYBA ${ }^{1}$, MARIA DO SOCORRO B. DE ARAÚJO ${ }^{2}$, BRIVALDO G. DE ALMEIDA ${ }^{3}$, FERNANDO C. ROLIM NETO ${ }^{4}$, EVERARDO V.S.B. SAMPAIO 5 and ANILDO M. CALDAS ${ }^{4}$}

\author{
${ }^{1}$ Empresa Brasileira de Pesquisa Agropecuária - Embrapa Solos UEP, Av. Antônio Falcão, 402, 51020-240 Recife, PE, Brazil \\ ${ }^{2}$ Universidade Federal de Pernambuco/UFPE, Departamento de Ciências Geográficas, \\ Av. Ac. Hélio Ramos, s/n, 50740-530 Recife, PE, Brazil \\ ${ }^{3}$ Universidade Federal Rural de Pernambuco/UFRPE, Departamento de Agronomia, Rua \\ Dom Manoel de Medeiros, s/n, Dois Irmãos, 52171-900 Recife, PE, Brazil \\ ${ }^{4}$ Universidade Federal Rural de Pernambuco/UFRPE, Departamento de Tecnologia Rural, \\ Rua Dom Manoel de Medeiros, s/n, Dois Irmãos, 52171-900 Recife, PE, Brazil \\ ${ }^{5}$ Universidade Federal de Pernambuco/UFPE, Departamento de Energia Nuclear, \\ Av. Prof. Luiz Freire, 1000, 50740-540 Recife, PE, Brazil
}

Manuscript received on October 2, 2018; accepted for publication on February 12, 2019

\begin{abstract}
How to cite: PARAHYBA RBV, ARAÚJO MSB, ALMEIDA BG, ROLIM NETO FC, SAMPAIO EVSB AND CALDAS AM. 2019. Water retention capacity in Arenosols and Ferralsols in a semiarid area in the state of Bahia, Brazil. An Acad Bras Cienc 91: e20181031. DOI 10.1590/0001-3765201920181031.
\end{abstract}

\begin{abstract}
One of the most serious problems in areas indicated for irrigation projects in the Brazilian Northeast region is the occurrence of sandy soils, known to have low moisture retention, but occurring in strategic locations in terms of water supply and geographical situation, and which can be used for agricultural purposes. The objective of this study was to evaluate the influence of particle size distribution and porosity on the water retention capacity of sandy soils in the semiarid area of the Northeast region. Soil bulk and particle densities, total porosity (macro, meso and microporosity), field capacity, permanent wilting point and soil-water retention curve were determined in samples of surface (A) and subsurface ( $\mathrm{C}$ or $\mathrm{Bw}$ ) horizons of ten sandy soil profiles. Particle size was determined subdividing the sand fraction into five classes. Higher amounts of the medium and fine sand fractions of the studied soils oriented their physical and hydric characteristics, being responsible for their great water retention. The arrangement of the fine silt, clay, fine sand and very fine sand particles may have provided a diversity of pore sizes and a good pore distribution, being responsible for the large proportion of micropores in the soils, allowing great water retention capacities.
\end{abstract}

Key words: soil-water retention curve, microporosity, pore-size distribution, sandy soils

\section{INTRODUCTION}

Sandy soils are underused for agriculture purposes due to the general idea that their high proportion

Correspondence to: Roberto da Boa Viagem Parahyba

E-mail: rbvparahyba@gmail.com

ORCID: http://orcid.org/0000-0002-7475-7490 of particles with large size $(2.0-0.05 \mathrm{~mm})$ leads to low water retention capacities (Or and Wraith 2002, Filizola et al. 2017). The particle size distribution can vary considerably among sandy soils, specifically the sand fraction, and therefore the water retention capacity of these soil varies (Franzmeier et al. 1960, Rivers and Shipp 
1972). This underuse affects particularly areas recommended for irrigation projects, since sandy soils predominate in many of these areas throughout the world. The semiarid Brazilian Northeast region has a large area of 969,589 $\mathrm{km}^{2}$ (Araújo 2011, Correia et al. 2011), part of it dedicated to irrigation projects, which occupied most of the more suitable soils. These projects in this Brazilian region and in other semiarid regions could expand to areas with sandy soils having moisture retention capacity higher than expected for these soils, since many of them occur in strategic sites in terms of water sources and geographic situation.

There are many factors affecting soil water retention, especially granulometry and structure (Mota et al. 2010, Klein et al. 2010, Reichardt 1990). Soil granulometry is one of the most stable physical characteristics and represents the quantitative distribution of mineral solid particles with respect to size. It is an important characteristic for soil description, identification and classification, with quantitative connotation (Ferreira 2010). Soil particle size affects the air space, especially due to the differences in terms of water retention, pore distribution and continuity (Deepagoda et al. 2011, Mosaddeghi et al. 2007), pore diameter (Reichardt and Timm 2004) and through its effects on soil water retention capacity and in the potential land uses (Siqueira 2007).

The retention and the conduction of water in soils are favored by a porous system that is stable and well distributed in the profile (Libardi 2010). Larger pores are responsible for soil aeration and water conduction under saturated conditions, while smaller pores act in water retention and conduction under unsaturated conditions (Cassel and Nielsen 1986). There are sandy soils with high proportions of fine and very fine sand, which must be studied with respect to their physicalhydraulic parameters. Franzmeier et al. (1960) and Rivers and Shipp (1978), studying soils with light texture, reported that the amount of available water varied significantly with the percentages of very fine sand and silt. This means that among sandy soils there are differences in water retention, guided by granulometric composition of the sand fraction. Similar results were found in a study by Filizola et al. (2017), in sandy soils with different managements in an agricultural area and in an area with Cerrado vegetation, in Guaraí municipality of, Tocantins state, Brazil. Manfredini et al. (1984) reported that in medium-textured soils and in Quartz Sands (Arenosols) the distribution of pores is predominantly determined by the granulometry of the sand fraction, highlighting that there is a significant correlation between the percentage of fine sand and the water storage capacity of sandy soils, which indicates greater microporosity. Soil-water retention curves have been used as an important tool in the description of the physical-hydraulic behavior and the mechanics of unsaturated soils. It is also essential in studies on soil quality intended to guide use practices and sustainable management of agricultural production systems (Machado et al. 2008, Silva et al. 2010). This study aimed to evaluate the influence of particle-size distribution and porosity on the water retention capacity of sandy soils in the Brazilian Northeastern semiarid.

\section{MATERIALS AND METHODS}

\section{SOILS IN THE STUDIED AREA}

The study was carried out in a settlement area located in the municipality of Glória ( $38^{\circ} 26^{\prime} 00^{\prime \prime}$ to $38^{\circ} 20^{\prime} 00^{\prime \prime} \mathrm{W}$, and $09^{\circ} 11^{\prime} 00^{\prime \prime}$ to $09^{\circ} 20^{\prime} 00^{\prime \prime} \mathrm{S}$ ), in irrigated areas in the semiarid region of Bahia state, Brazil. Sandy soils of the Arenosol and mediumsized particle texture of Ferralsol classes (IUSS Working Group WRB-FAO 2014), both developed from sandstone sediments of the Tucano Basin, are predominant in the studied area (Oliveira Neto et al. 2007).

Three subareas with Ferralsols and seven subareas with Arenosols were selected. Ferralsols 
were represented by Haplic Ferralsols and Arenosols by Dystric Chromic Siderolic Arenosols and Dystric Rubic Siderolic Arenosols (Table I).

The soil profiles 1-Dystric Chromic Siderolic Arenosol and 1-Dystric Rubic Siderolic Arenosol are different from the other Arenosols' profiles with respect to their granulometry, as well as for having deeper subsurface horizon, loamy sand texture in the limit to sandy loam, and a weak structure development, which was an important parameter to verify this characteristic in the properties of soil water retention.

\section{LABORATORIAL SOIL ANALYSIS}

Bulk density, granulometry, particle density and water retention capacity were determined in the collected soil samples. Physical-hydraulic tests were performed, determining soil water retention curve (SWRC), water content at field capacity (Fc) and permanent wilting point (Pwp). Pore-size distribution was estimated through a mathematical equation adapted from Bouma (1991).

For the determination of soil density, the samples were collected using a Köpeck core, with

TABLE I

Soil classes according to the IUSS Working Group WRBFAO (2014), sampled in the municipality of Glória, Bahia state, Brazil.

\begin{tabular}{c}
\hline SOIL CLASSES \\
\hline 1-Haplic Ferralsol (Arenic, Dystric, Ochric) \\
2-Haplic Ferralsol (Arenic, Dystric, Ochric) \\
3-Haplic Ferralsol (Arenic, Dystric, Ochric) \\
DYSTRIC RUBIC ARENOSOLS \\
1-Dystric Rubic Siderolic Arenosol (Alumic, Hydrophobic) \\
2-Dystric Rubic Siderolic Arenosol (Hydrophobic) \\
3-Dystric Rubic Siderolic Arenosol (Hydrophobic) \\
DYSTRIC CHROMIC ARENOSOLS \\
1-Dystric Chromic Siderolic Arenosol (Alumic, Hydrophobic) \\
2-Dystric Chromic Siderolic Arenosol (Hydrophobic) \\
3-Dystric Chromic Siderolic Arenosol (Alumic, Hydrophobic) \\
4-Dystric Chromic Siderolic Arenosol (Hydrophobic) \\
\hline
\end{tabular}

three replicates for each horizon of the profile. Determination of granulometry, particle density and water retention capacity at low tensions were performed with three replicates, using the methods described in the Manual of Soil Analysis Methods (Texeira et al. 2017). The fractions silt $(0.05-0.002$ $\mathrm{mm})$, clay $(<0.002 \mathrm{~mm})$ and sand $(<2-0.05 \mathrm{~mm})$ were separated, and the latter was further separated into the fractions very coarse sand $(<2.0-1.0$ $\mathrm{mm})$, coarse sand $(<1.0-0.5 \mathrm{~mm})$, medium sand $(<0.5-0.25 \mathrm{~mm})$, fine sand $(<0.25-0.10 \mathrm{~mm})$ and very fine sand $(<0.10-0.05 \mathrm{~mm})$ (Soil Science Division Staff. 2017). For SWRC determination, in the laboratory, the horizons $\mathrm{A}$ and $\mathrm{C}$ of Arenosols and $\mathrm{A}$ and $\mathrm{Bw}$ (deeper, between 150 and $200 \mathrm{~cm}$ ) of Ferralsols were selected in each soil profile in order to form a pair of horizons for each area.

Bulk samples of sandy layers of representative Arenosols were collected to obtain a sufficient amount of pure sand. In these samples, a sand fractionation of reference to the region (very coarse, coarse, medium, fine and very fine sand fractions) was performed. Furthermore, in each separated pure sand fraction the water retention capacity was determined, and a corresponding soil water retention curve (SWRC) was made.

For the physical-hydraulic tests and the analyses, disturbed soil samples contained in volumetric cores $(\varnothing$, diameter $=5 \mathrm{~cm} \mathrm{x} \mathrm{h}$, height $=$ $2.5 \mathrm{~cm}$ ) were collected from surface and subsurface horizons of the 10 (ten) selected profiles, in three replicates of each sample per horizon. The method of Richards (1947) was used for SWRC determination, subjecting soil samples to tensions of 10,33 and $100 \mathrm{kPa}$ in the pressure chamber with a 1-bar ceramic plate. For tensions of 1,000 and 1,500 $\mathrm{kPa}$, a Richards' extractor with a 15-bar ceramic plate was used (Texeira et al. 2017). Soil samples were also subjected to water column tensions of 40 , 60,80 and $100 \mathrm{~cm}$, through a tension table, with three replicates of each sample per horizon at each tension (Texeira et al. 2017). The SWRC was made 
by relating the potentials with the respective values of the obtained volumetric water contents.

SWRC data were adjusted according to the procedures suggested by van Genuchten (1980), using the program "Retention Curve" - RetC (van Genuchten et al. 1994) for the determination of the parameters used in the equation 1.

$$
\theta=\theta r+\frac{(\theta s-\theta r)}{\left[1+(\alpha \Psi)^{n}\right]^{m}}
$$

Equation 1

where $\theta$ is the volumetric water content $\left(\mathrm{m}^{3} \mathrm{~m}^{-3}\right)$ at the respective potential $(\Psi)$, after equilibrium with the applied potential; $\theta \mathrm{s}$ is the volumetric water content determined at saturation $\left(\mathrm{m}^{3} \mathrm{~m}^{-3}\right)$; $\theta \mathrm{r}$ is the residual volumetric water content $\left(\mathrm{m}^{3} \mathrm{~m}^{-3}\right)$ determined at the permanent wilting point (at $1,500 \mathrm{kPa}) ; \Psi$ is the soil water potential (mwc); and $\alpha\left(\mathrm{m}^{-1}\right), \mathrm{n}$ and $\mathrm{m}$, the empirical parameters of the equation. The parameter $\mathrm{m}$ was calculated using the expression $\mathrm{m}=1-1 / \mathrm{n}$ (Mualem 1976). Poresize distribution was based on the mathematical expression (Equation 2), adapted from Bouma (1991).

$D=\left(\frac{4 \sigma \cos \alpha}{\rho_{a} g|\Psi|}\right)$

Equation 2

where $\mathrm{D}$ is pore diameter $(\mu \mathrm{m}) ; \sigma$ is the water surface tension $\left(\mathrm{N} \mathrm{m}^{-1}\right) ; \alpha$ is the contact angle between the meniscus and the capillary tube wall, assumed as equal to $0^{\circ}$; $\rho$ a is the water density $(\mathrm{kg}$ $\left.\mathrm{m}^{-3}\right)$; $\mathrm{g}$ is the acceleration of gravity $\left(\mathrm{m} \mathrm{s}^{-2}\right)$; and $|\Psi|$ is the absolute value of the water tension in soil pores (mwc).

Assuming $\sigma=73.575 \times 10^{-3} \mathrm{~N} \mathrm{~m}^{-1}$, $\rho \mathrm{a}=$ $1,000 \mathrm{~kg} \mathrm{~m}^{-3}$ and $\mathrm{g}=9.81 \mathrm{~m} \mathrm{~s}^{-2}$, the equation 2 can be simplified and the pore diameter $(\mu \mathrm{m})$ was calculated by the equation 3 .

$$
D_{(\mu m)}=\frac{30}{\Psi}
$$

Equation 3
Therefore, pore-size distribution was determined by relating pore diameters to the tensions applied to the samples during SWRC tests. Thus, macropores $(\mathrm{D}>300 \mu \mathrm{m})$ were defined as pores that drain water from $1 \mathrm{kPa}$ on, mesopores as those draining water between the tensions $>1 \mathrm{kPa}$ and $6 \mathrm{kPa}(50 \mu \mathrm{m}<\mathrm{D}<300 \mu \mathrm{m})$, and micropores as those draining water at tensions $>6 \mathrm{kPa}(\mathrm{D}<50$ $\mu \mathrm{m})$ (Prevedello 1996).

Porosity was determined according to the saturation method, assuming that the volume of pores (Vpores) is equal to the volume of water filling soil pores (saturation). Thus, soil samples contained in the cores were saturated and the core-sample sets were weighed $(\mathrm{MSsat}=$ mass of saturated soil), dried in an oven and weighed again $\left(\operatorname{MDS} 105{ }^{\circ} \mathrm{C}=\right.$ mass of the soil dried at 105 $\left.{ }^{\circ} \mathrm{C}\right)$. Vpores was then calculated by the difference between MSsat and MDS105 ${ }^{\circ} \mathrm{C}$, calculating soil porosity according to the equation 4 .

$P=\frac{\text { Vpores }}{\text { Vtotal }}$

Equation 4

where $\mathrm{P}$ is total soil porosity $\left(\mathrm{m}^{3} \mathrm{~m}^{-3}\right)$; Vpores, the volume of pores $\left(\mathrm{m}^{3}\right)$ and Vtotal, the total soil volume $\left(\mathrm{m}^{3}\right)$, represented by the volume of the volumetric core used in the soil sampling $\left(\pi r^{2} h\right)$.

\section{IN-SITU DETERMINATION OF WATER RETENTION} CAPACITY

In-situ tests with twelve replicates were performed for the measurement of water retention capacity. For this, in a site close to the soil profile, in each one of the ten subareas, six iron grids with dimensions of $100 \mathrm{~cm} \times 100 \mathrm{~cm}$ and a height of 25 $\mathrm{cm}$ were installed, inside which water was added using an amount sufficient for the determination of the water retention capacity, according to Texeira et al. (2017). The samples were collected using a soil auger and stored in properly sealed aluminum cans; then, the samples were weighed and dried in an oven at $105^{\circ} \mathrm{C}$. 


\section{RESULTS AND DISCUSSION}

\section{SIZE DISTRIBUTION OF SOLID PARTICLES AND SOIL POROSITY}

The granulometric composition of the soils in the ten studied subareas is essentially sandy (Table II), with sand contents in Ferralsols from 898 to 905 $\mathrm{g} \mathrm{kg}^{-1}$ in surface horizons, and from 750 to $808 \mathrm{~g}$ $\mathrm{kg}^{-1}$ in subsurface horizons. In the Arenosols, these contents ranged from 875 to $944 \mathrm{~g} \mathrm{~kg}^{-1}$ in surface horizons and from 814 to $906 \mathrm{~g} \mathrm{~kg}^{-1}$ in subsurface horizons.

Both soil classes showed textural variation in the subsurface, changing from sand to loamy sand, which indicates an increment of clay and silt in the subsurface in most of the studied soil profiles. As to the size distribution of particles from the sand fraction, a predominance of medium and fine sand was observed in all profiles (Table II).

The variation in soil particle size is directly related to the change in water retention properties (River and Shipp 1972, Silva et al. 2006, Fidalski et al. 2013). In the case of materials with greater particle size heterogeneity, the effective pore size can be reduced by the effect of empty spaces between larger grains being occupied by smaller particles (packaging phenomenon); Thus, it is possible for certain particle size distributions to cause soil compaction and minimize pore space (Donagemma et al. 2016). Riva (2010) observed that a proportion with about $30 \%$ of small particles favors packaging. According to Giménez et al. (1997), soils with the presence of smaller particles are characterized by the presence of smaller pores, while the larger particles create large pores. The high medium and fine sand values $(<0.5-0.25$ $\mathrm{mm}$ and $<0.10-0.05 \mathrm{~mm}$, respectively) found in the sandy soils of this study promote a capillary distribution network with smaller diameter pores, allowing retention of water between soil particles and a slower movement of the soil solution. This can favor a smaller loss by percolation and consequently higher water storage in these soils, allowing a supply of water to the cultures for a longer period.

Sandy soils, in general and especially those in which coarse sand prevails over fine sand, have great limitation related to the available water storage capacity. However, the studied sandy soils have a small proportion of sands with larger diameters $(<2.0-1.0 \mathrm{~mm}$ and $<1.0-0.5 \mathrm{~mm}$, very coarse and coarse, respectively). These sizes of coarser particles represent only $6-16 \%$ of the total sand. The high percentages of finer particles (0.5 - $0.25 \mathrm{~mm}$ and $0.25-0.10 \mathrm{~mm}$, medium and fine sand, respectively), between 40 and $75 \%$ of the total sand, combined with their clay contents $(<0.02 \mathrm{~mm})$, despite low (4 to $15 \%)$, probably contributed to increasing water retention in these soils.

Muggler et al. (1996) explained that the higher water retentions in sandy soils are due not only to their content of fine sand, but also to the combined effect of this fraction with clay, especially in soils with very low silt and clay contents, as verified in this research. The studied soils, although sandy, may have less water limitation, because they present a great quantity and variability of sand subfractions with smaller diameters, mainly the medium and fine sand. In relation to this, it was observed that all soil profiles showed predominance of the sand and fine sand fractions over the other subfractions (Table II).

The physical-hydraulic behavior of sandy soils varies according to the granulometry of the sand fraction. Sandy soils with finer particles have higher water retention than sandy soils with coarser particles (Mecke et al. 2002, Fidalski et al. 2013). The more subdivided this fraction is (medium, fine and very fine sand), with less uniform sizes and forms, the higher will be the percentage of medium $(50 \mu \mathrm{m}<\varnothing<30 \mu \mathrm{m})$ and small $(\varnothing<50 \mu \mathrm{m})$ porous spaces between soil particles, which will contribute to greater water storage, reported later 
TABLE II

Granulometric composition of sandy soils in the municipality of Glória, Bahia state, Brazil, including sand fractionation according to the Soil Science Division Staff (2017).

\begin{tabular}{|c|c|c|c|c|c|c|c|c|}
\hline \multirow{4}{*}{ Horizon } & \multirow{4}{*}{ Depth } & \multicolumn{7}{|c|}{ Granulometric composition } \\
\hline & & \multicolumn{5}{|c|}{ Sand fraction } & \multirow{3}{*}{ Silt } & \multirow{3}{*}{ Clay } \\
\hline & & Very coarse & Coarse & $\begin{array}{c}\text { Medium } \\
\mathrm{mm}\end{array}$ & Fine & Very fine & & \\
\hline & & $(2.0-1.0)$ & $(1.0-0.5)$ & $(0.5-0.25)$ & $(0.25-0.1)$ & $(0.1-0.05)$ & & \\
\hline & ${ }_{-}^{\mathrm{cm}}$ & & 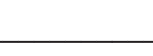 & 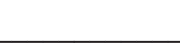 & $\mathrm{g} \mathrm{kg}^{-1}$ & & & \\
\hline & & & Haplic & $\begin{array}{c}\text { Ferralsol (Are } \\
1\end{array}$ & nic, Dystric, & Ochric) & & \\
\hline A & $0-12$ & 37 & 129 & 334 & 326 & 72 & 52 & 50 \\
\hline Bw3 & $150-208+$ & 85 & 122 & $\begin{array}{r}190 \\
2\end{array}$ & 281 & 72 & 100 & 150 \\
\hline A & $0-12$ & 25 & 110 & 339 & 356 & 75 & 45 & 50 \\
\hline Bw3 & $160-202+$ & 30 & 54 & $\begin{array}{r}196 \\
3\end{array}$ & 361 & 122 & 107 & 130 \\
\hline A & $0-13$ & 16 & 89 & 324 & 387 & 84 & 30 & 70 \\
\hline $\mathrm{Bw}$ & $150-200+$ & 33 & 72 & 201 & 397 & 105 & 82 & 110 \\
\hline & & & Dystric F & $\begin{array}{c}\text { ubic Siderolic } \\
1\end{array}$ & Arenosol & & & \\
\hline A & $0-10$ & 33 & 83 & 305 & 407 & 100 & 12 & 60 \\
\hline $\mathrm{C} 4$ & $162-210+$ & 22 & 67 & $\begin{array}{r}256 \\
2\end{array}$ & 379 & 109 & 67 & 100 \\
\hline A & $0-11$ & 15 & 111 & 351 & 357 & 86 & 30 & 50 \\
\hline $\mathrm{C} 4$ & $150-206+$ & 38 & 114 & $\begin{array}{r}293 \\
\mathbf{3}\end{array}$ & 290 & 79 & 86 & 100 \\
\hline A & $0-13$ & 19 & 130 & 320 & 389 & 65 & 27 & 50 \\
\hline $\mathrm{C} 4$ & $156-206+$ & 37 & 91 & 252 & 362 & 86 & 82 & 90 \\
\hline & & & Dystric Cl & $\begin{array}{c}\text { romic Siderol } \\
1\end{array}$ & ic Arenosol & & & \\
\hline A & $0-10$ & 23 & 104 & 332 & 352 & 64 & 65 & 60 \\
\hline $\mathrm{C} 5$ & $176-211+$ & 29 & 88 & $\begin{array}{r}265 \\
2\end{array}$ & 364 & 110 & 44 & 100 \\
\hline $\mathrm{A}$ & $0-10$ & 10 & 106 & 355 & 365 & 79 & 24 & 60 \\
\hline $\mathrm{C} 4$ & $140-200+$ & 12 & 107 & $\begin{array}{r}329 \\
\mathbf{3}\end{array}$ & 353 & 79 & 40 & 80 \\
\hline A & $0-10$ & 25 & 137 & 380 & 350 & 52 & 16 & 40 \\
\hline $\mathrm{C} 4$ & $140-210+$ & 23 & 109 & $\begin{array}{r}333 \\
4\end{array}$ & 366 & 75 & 34 & 60 \\
\hline A & $0-12$ & 26 & 145 & 381 & 313 & 69 & 17 & 50 \\
\hline $\mathrm{C} 4$ & $130-203+$ & 15 & 95 & 371 & 370 & 71 & 28 & 50 \\
\hline
\end{tabular}

with the data of Table III. This can be justified by the better arrangement of particles, resulting in a smaller diameter in the capillary network, which allows the presence of a thicker water film retained between particles, and in a slower movement of the soil solution and, consequently, a higher amount of water retained in the soil (Kiehl 1979).
Besides the distribution of frequency of soil particle sizes, the form and the way they are grouped in the soil can create arrangements that influence soil packing, compaction and water storage (Abrahão et al. 1998).

Due to the very low contents of very coarse and very fine sand in all the soil samples, a new classification for the sand fraction was adopted in 
TABLE III

Organic matter and physical characteristics of sandy soils from the municipality of Glória, Bahia state, Brazil.

\begin{tabular}{|c|c|c|c|c|c|c|c|c|c|c|}
\hline \multirow{3}{*}{ Horizon } & \multirow{3}{*}{$\begin{array}{c}\mathrm{OM} \\
\mathrm{g} \mathrm{kg}^{-1} \\
\end{array}$} & \multicolumn{7}{|c|}{ Porosity } & \multirow{2}{*}{ Bd } & \multirow{2}{*}{ Pd } \\
\hline & & 1 & 2 & 3 & 4 & Micro & Total & Estimated & & \\
\hline & & \multicolumn{4}{|c|}{ 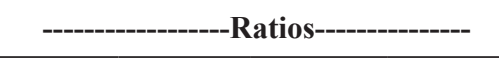 } & \multicolumn{3}{|c|}{ - } & \multicolumn{2}{|c|}{$---\mathrm{g} \mathrm{cm}^{-3}--$} \\
\hline \multicolumn{11}{|c|}{ Haplic Ferralsol (Arenic, Dystric, Ochric) } \\
\hline \multicolumn{11}{|c|}{1} \\
\hline A & 9.5 & 0.53 & 0.24 & 0.55 & 0.45 & 15.72 & 35.13 & 38.13 & 1.59 & 2.57 \\
\hline Bw3 & 0.3 & 0.05 & 0.03 & 0.30 & 0.70 & 23.95 & 34.12 & 39.40 & 1.60 & 2.64 \\
\hline \multicolumn{11}{|c|}{2} \\
\hline A & 2.1 & 0.09 & 0.05 & 0.45 & 0.55 & 17.93 & 32.68 & 35.43 & 1.64 & 2.54 \\
\hline Bw3 & 0.3 & 0.07 & 0.05 & 0.31 & 0.69 & 23.29 & 33.88 & 38.40 & 1.62 & 2.63 \\
\hline \multicolumn{11}{|c|}{3} \\
\hline A & 2.7 & 0.06 & 0.03 & 0.44 & 0.56 & 18.77 & 33.24 & 38.10 & 1.61 & 2.60 \\
\hline $\mathrm{Bw}$ & 0.2 & 0.001 & 0.001 & 0.14 & 0.86 & 27.31 & 31.80 & 37.90 & 1.64 & 2.64 \\
\hline \multicolumn{11}{|c|}{ Dystric Rubic Siderolic Arenosol } \\
\hline \multicolumn{11}{|c|}{1} \\
\hline A & 3.4 & 0.05 & 0.03 & 0.43 & 0.57 & 18.08 & 31.74 & 36.76 & 1.60 & 2.53 \\
\hline $\mathrm{C} 4$ & 1.4 & 0.00 & 0.002 & 0.15 & 0.85 & 26.02 & 30.49 & 34.88 & 1.68 & 2.58 \\
\hline \multicolumn{11}{|c|}{2} \\
\hline A & 3.1 & 0.21 & 0.10 & 0.53 & 0.47 & 18.14 & 38.21 & 39.90 & 1.58 & 2.63 \\
\hline $\mathrm{C} 4$ & 0.3 & 0.21 & 0.12 & 0.44 & 0.56 & 22.42 & 39.91 & 38.20 & 1.62 & 2.62 \\
\hline \multicolumn{11}{|c|}{3} \\
\hline A & 5.5 & 0.14 & 0.07 & 0.51 & 0.49 & 18.10 & 37.14 & 39.30 & 1.56 & 2.57 \\
\hline $\mathrm{C} 4$ & 0.5 & 0.01 & 0.01 & 0.25 & 0.75 & 26.44 & 35.31 & 37.50 & 1.65 & 2.64 \\
\hline \multicolumn{11}{|c|}{$\begin{array}{l}\text { Dystric Chromic Siderolic Arenosol } \\
1\end{array}$} \\
\hline A & 10.0 & 0.06 & 0.03 & 0.42 & 0.58 & 23.08 & 39.48 & 40.60 & 1.58 & 2.66 \\
\hline C5 & 1.2 & 0.01 & 0.01 & 0.27 & 0.73 & 27.05 & 36.93 & 37.26 & 1.65 & 2.63 \\
\hline \multicolumn{11}{|c|}{2} \\
\hline A & 7.1 & 0.47 & 0.17 & 0.63 & 0.37 & 14.08 & 38.35 & 38.00 & 1.63 & 2.63 \\
\hline $\mathrm{C} 4$ & 1.2 & 0.61 & 0.24 & 0.60 & 0.40 & 14.96 & 37.18 & 37.10 & 1.63 & 2.59 \\
\hline \multicolumn{11}{|c|}{3} \\
\hline A & 8.1 & 0.57 & 0.26 & 0.54 & 0.46 & 16.58 & 36.05 & 39.20 & 1.60 & 2.63 \\
\hline $\mathrm{C} 4$ & 1.0 & 0.07 & 0.04 & 0.43 & 0.57 & 20.27 & 35.70 & 36.50 & 1.67 & 2.63 \\
\hline \multicolumn{11}{|c|}{4} \\
\hline A & 17.3 & 1.85 & 0.56 & 0.69 & 0.31 & 11.86 & 38.87 & 33.85 & 1.70 & 2.57 \\
\hline $\mathrm{C} 4$ & 2.4 & 0.04 & 0.02 & 0.45 & 0.55 & 17.13 & 31.25 & 35.00 & 1.69 & 2.60 \\
\hline
\end{tabular}

Observation: $\mathrm{OM}=$ organic matter; $1=$ macroporosity/microporosity ratio; 2 = macroporosity/total porosity ratio; $3=(\mathrm{macro}+$ $\mathrm{meso}$ )/total porosity ratio; 4 = microporosity/total porosity ratio; $\mathrm{Bd}=$ bulk density; $\mathrm{Pd}=$ particle density.

this study, separating it into three levels: coarse sand (formed by coarse and very coarse sands), medium sand and fine sand (formed by fine and very fine sands).

Soil granulometric analysis was decisive to separate the profiles Dystric Rubic 3, Dystric Chromic 1, 2, 3 and 4 from Dystric Rubic 1 and 2, especially through their silt + clay contents (Table II). Profiles Dystric Rubic 1 and 2, despite having higher silt + clay contents than the others, showed more developed morphological organization in the subsurface horizons $\mathrm{C} 5$ and $\mathrm{C} 4$, respectively, promoting better physical characteristics, which were intermediate between Ferralsols and 
Arenosols (Table II). Although the profiles Dystric Rubic 3 and Dystric Chromic 2 had slightly higher silt + clay contents in subsurface horizons (C4), their morphological characteristics in the in-situ test were typical of Arenosols.

Total porosity was relatively low, as generally is observed in sandy soils, compared with clayey and silty soils (Bruand et al. 2005), in a decreasing gradient in the subsurface (Table III). In the A horizons of Ferralsols, total porosity was approximately $34 \%$, and in the Bw horizons the values were lower, about $33 \%$. On the other hand, in the A horizons of Arenosols, the values were about $37 \%$ higher than in $\mathrm{C}$ horizons, which showed values of $35 \%$.

Soil particle density $(\mathrm{Pd})$ had values between 2.53 and $2.66 \mathrm{~g} \mathrm{~cm}^{-3}$ in all the horizons of both soil classes. These values are within the density range for quartz, a basic mineral constituent of sandy soils (Kohnke 1968). Weil and Brady (2016) observed particle densities from 2.60 to $2.75 \mathrm{~g} \mathrm{~cm}^{-3}$ in sandy soils.

Soil bulk density $(\mathrm{Bd})$ in this study was within the range found in the literature for sandy soils, both for Ferralsols, with values from 1.59 to 1.64 $\mathrm{g} \mathrm{cm}^{-3}$ (Table III), similar to those observed by Ker (1997) and Cunha et al. (2005), and Arenosols, with values from 1.58 to $1.70 \mathrm{~g} \mathrm{~cm}^{-3}$, which are within the ranges observed by the São Francisco's Hydroelectric Company - CHESF (1987, 1989a, b), and by Cunha et al. (2005) and Schioavo et al. (2010). Bd values tended to be lower in surface horizons (Table III). This fact can be justified by the higher organic matter (OM) content in surface horizons (Table III), which promotes a reduction in soil density. Besides OM, the literature claims that higher $\mathrm{Fe}$ and $\mathrm{Al}$ oxides contents in the soil have an influence on the increase of soil particle density (Reinert and Reichert 2006). The Fe and Al oxides contents were low due to inherited characteristic of their parent material which are sandy sediments of the Tucano Basin. It can be concluded that OM had a high contribution to soil density values and, consequently, to pore size distribution. For Reinert and Reichert (2006), soil density tends to increase in subsurfaces of the profile. This is probably due to lower OM contents, low aggregation of soil particles, small amounts of roots and higher compaction caused by the mass of overlying layers.

The influence of organic matter on the values of total porosity was the most remarkable factor in the differentiation between surface and subsurface horizons, especially in Arenosols, which have higher OM contents in the A horizons and lower ones in the $\mathrm{C}$ horizons (Table III). However, the large contents of the fine sand fraction may have been responsible for the low values of total porosity, as observed by Resende and Rezende (1983). These authors reported that high contents of fine sand in sandy soils can produce particle packing, reflected by higher densities and compaction, with decreased total porosity. Indeed, if soil particles are arranged in close contact, there is a predominance of solids in the sample and less empty spaces, resulting in the decrease of porosity (Ribeiro et al. 2007). However, the more subdivided the solid particles (for sand: medium, fine and very fine) and the less uniform the particle sizes, the larger will be the spaces between them, contributing to greater water retention (Ridgway and Tarbuck 1968, Castro and Pandofeli 2009). At first, this particle arrangement contradicts the classical theory that sandy soils have predominantly low water retention. Therefore, for a better understanding of the process of water retention in sandy soils, it is necessary to subdivide the sand fraction into subfractions with the distribution of the proportion of their pores into macro, meso and micro sizes (Table III).

Among the three existing classes of pores, macroporosity, in general, showed the lowest values and was more expressive in surface horizons, especially in Dystric Rubric 3, Dystric Chromic 1, 2, 3 and 4, which have the highest OM contents in the A horizons (Table III). 
The macroporosity was considered as those pores draining water above $-1 \mathrm{kPa}$ (pore diameter $>$ $300 \mu \mathrm{m}$ ), as suggested by Prevedello (1996), while mesopores drained between -1 and $-6 \mathrm{kPa}$, and micropores, below $-6 \mathrm{kPa}$. Some authors consider macroporosity as the pores that drain water above $-6 \mathrm{kPa}$, summarizing the porosity classification into only two classes: macro and microporosity.

Separation of solid particles into more detailed sizes, which showed great variability, and the determination of macro, meso and micropores allowed a better understanding on the processes of water retention in these sandy soils, evidencing a hydraulic behavior much different from the one conventionally reported for soils with this texture. However, when the values of macroporosity and mesoporosity were added, considering the total as macropores, the results showed the same tendency of lower values compared with microporosity, even when they were evaluated separately, i.e., macroporosity $<$ mesoporosity $<$ microporosity.

The proportions of micropores were higher than those of macropores, particularly in the subsurface horizons (Table III). This occurred both in $\mathrm{Bw}$ horizons of Ferralsols and in $\mathrm{C}$ horizons of Arenosols, sand particles having different diameters and arrangement from those in surface horizons, which, combined with the higher silt and clay contents, allow greater microporosity in these horizons and, consequently, higher water retention capacity.

Soil porosity can also be evaluated through the distribution of pores per size by relating the volume of macropores to the total volume of pores in a soil sample (macroporosity/total porosity ratio; Table III).

According to Genro Jr et al. (2009), this ratio has an ideal value around 0.33 and indicates good relationship between aeration capacity and water retention in the soil. For Taylor and Aschcroft (1972) and Silva et al. (2004), macropore values must be higher than $0.10 \mathrm{~m} 3 \mathrm{~m}^{-3}(10 \%)$, allowing gas exchanges that favor root growth. In addition, the presence of pores $>145 \mu \mathrm{m}$ in the soil in ideal percentages (in theory) is of fundamental importance for the process of soil water infiltration (Hillel 2003). In this study, the presence of a higher proportion of micropores, compared with macropores, explains the obtained low values of the macroporosity/total porosity ratio (Table III). For Weil and Brady (2016), soils with $1 / 3$ of macropores $(34 \%)$ and $2 / 3$ of micropores $(66 \%)$ have adequate conditions for the development of agricultural crops. However, Camargo and Alleoni (1997) considered as ideal a soil with $50 \%$ of its total volume of porous space.

\section{SOIL-WATER RETENTION CURVES}

The soil-water retention curves (SWRC) reflected the hydraulic differences between the studied soils, and three distinct situations occurred between the soil classes (Figures 1 to 4 ).

In the class of Ferralsols, subsurface horizons (Bw) showed greater water retention than A horizons along the entire curve (Figure 1), proving that in $\mathrm{Bw}$ horizons the finer fractions play a fundamental role in water retention. Indeed, this greater water retention in Bw horizons is mainly due to the presence of very fine particles (very fine sand, silt and clay) with a total value of 603 to $720 \mathrm{~g} \mathrm{~kg}^{-1}$, whereas in the horizon A the value were from 500 to $571 \mathrm{~g} \mathrm{~kg}^{-1}$ (Table II). Together, these particles contributed to the higher amounts of micropores in the Bw horizons (Table III), expressed by microporosity with values of 23 to $27 \%$ of the total porosity (Table III), while the A horizon presented values of 15 to $18 \%$ of the total porosity. As a consequence, these porosities resulted in increasing capacities to retain water, even at high tensions $(1,500 \mathrm{kPa} \cong 15,000 \mathrm{cwc} \cong$ $4.2 \log \mathrm{cwc}$ ), when the soils reached the permanent wilting point (Pwp). 

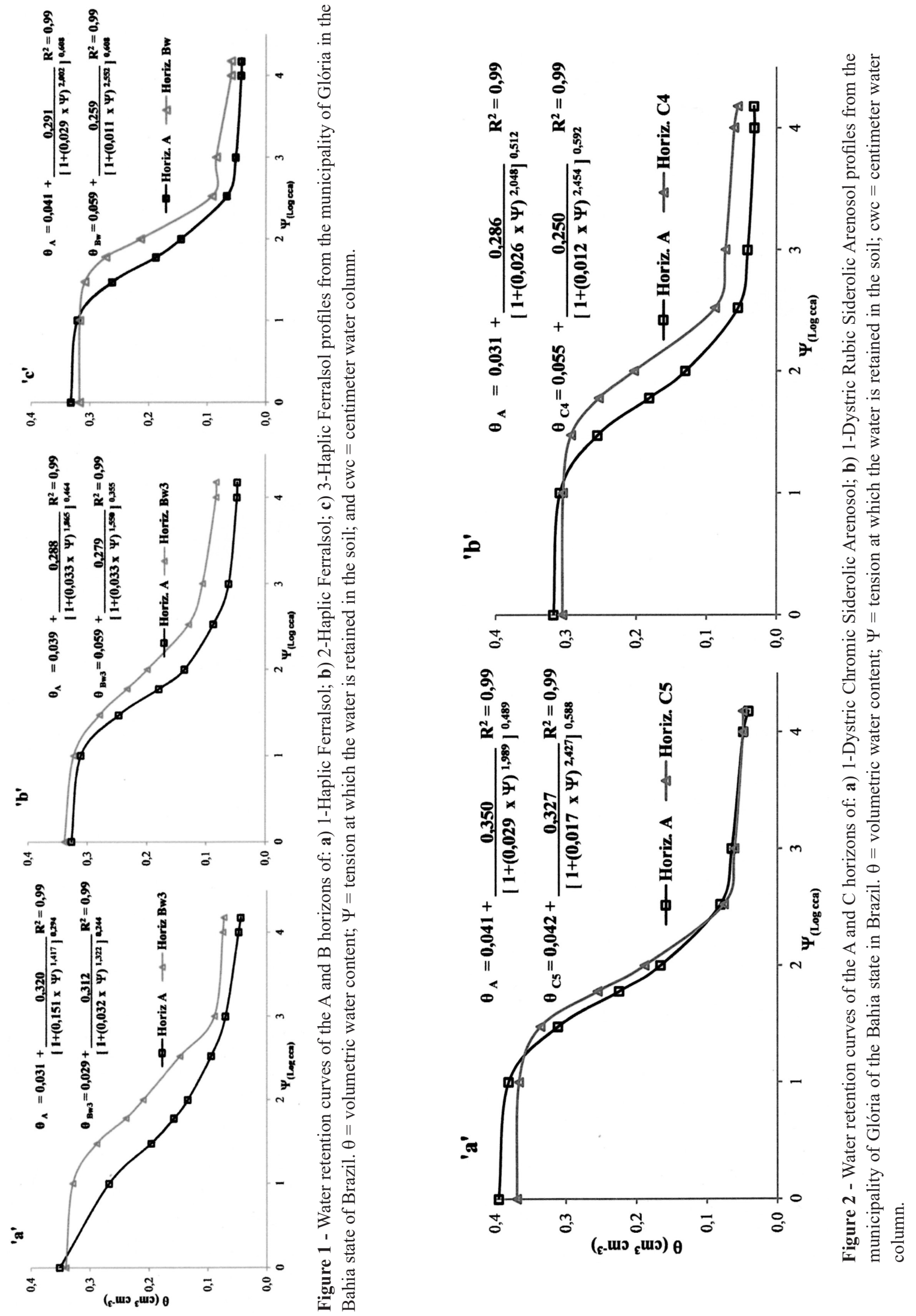
According to the SWRC of Dystric Rubic 1 and 2 (Figure 2), these profiles have hydraulic behaviors more similar to those of Ferralsols than to those of the profiles Dystric Rubic 3, Dystric Chromic 1, 23 e 4, (Figures 3 and 4). Very fine particles were present in greater amounts in Arenosols, represented by the profiles Dystric Rubic 4 and 2, and were responsible for this greater similarity with Ferralsols in Dystric Rubic 3, Dystric Chromic 1, 2, 3 and 4, with respect to water retention capacity (Figures. 1 and 2).

Among the Arenosols (Dystric Rubic 3, Dystric Chromic 1, 2, 3 and 4), those represented by the profiles Dystric Chromic 3 and 4 showed hydraulic behavior different from the others, differentiating from the tension at field capacity $(-10 \mathrm{kPa} \cong 100$ $\mathrm{cwc} \cong 2.0 \log \mathrm{cwc}$, Figure 4$)$. From this tension on, there was greater water retention in the A horizons than in the subsurface horizons, differently from the other Arenosols and Ferralsols. The greater organic matter content in the A horizons of Dystric Chromic 3 and 4 , with values of 8.1 and $17.3 \mathrm{~g} \mathrm{~kg}^{-1}$ (Table III), respectively, seems to explain this behavior of greater water retention when the pores are subjected to high tensions (permanent wilting point). In this regard, Dexter (2004) observed significant effect of organic matter on water retention in sandy soils.

Another important aspect that differentiates the water retention capacity of the studied soils is their different pore-size distributions, evidenced by the SWRC slope and confirmed by the values of the " $n$ " parameter of Eq. 1 of van Genuchten (Table IV). In addition, high values of the coefficient of determination $\left(\mathrm{R}^{2}\right)$ can be observed in Figures 1 to 4 , which indicate a good correlation of Eq. 1 to the SWRC data of the studied soils.

Almost all the infiltrated water in sandy soils is retained at higher potentials (low tensions), with the occurrence of an abrupt decrease in water content from that of field capacity ( 0 $\mathrm{kPa}$ ). This characteristic in sandy soils is due to the predominance of macroporosity (Reichardt
1990). Hillel (1998) affirmed that, with the range of low tensions, water retention depends mainly on capillarity and pore-size distribution; thus, it is affected by soil structure.

Athigh tensions, the phenomenon of adsorption is responsible for water retention, influenced by granulometry and specific surface area of the soil (Hillel 1998, Reichardt and Timm 2004). In general, in well-structured soils there is greater presence of particles that are arranged in aggregates, so there is a predominance of voids in the soil and the porosity will be high (Ribeiro et al. 2007), which leads to a better water retention. According to Reeve and Carter (1991), compressed soils are characterized by lower water retention at low tensions ( 0 to 100 $\mathrm{kPa}$ ), resulting from the reduction of porosity, especially macropores, which are filled with gravitational water in the largest matric potentials (less negative). Conversely, an increase in water retention is usually observed at the lower potentials (more negative) as result of increased micro porosity, increasing the capillary water volume. In the present study, water retention was higher in all the subsurface horizons of the studied soils, since they presented higher volumetric moisture values $\left(\theta \mathrm{cm}^{3} \mathrm{~cm}^{-3}\right)$ than the surface horizons, expressed by the SWRC according to figure 1, 3 and 4, and data from tableIV, discussed ahead. This greater retention in subsurface horizons occurred because of the influence of finer soil fractions (River and Shipp 1978, Silva et al. 2006, Filizola et al. 2017). However, the surface horizons of the Dystric Chromic Siderolic Arenosol profiles 3 and 4, from the tension of $10 \mathrm{kPa}$ on (Figure 4), have greater water retention than their subsurface horizons.

As they usually have larger pores, sandy soils are more rapidly emptied at low tensions, leaving only small amounts of water retained at lower (more negative) potentials. This fact, according to Hillel (1982), explains the steep slope of the SWRC for these soils. According to the values of water retention obtained in the present study in 
TABLE IV

Parameters of the van Genuchten Equation 1 for horizons of sandy soil profiles from the municipality of Glória, Bahia state, Brazil, by the method of Richards' chamber.

\begin{tabular}{|c|c|c|c|c|c|}
\hline \multirow{2}{*}{$\begin{array}{c}\text { Horizon/ } \\
\text { Depth } \\
\text { (cm) }\end{array}$} & \multicolumn{5}{|c|}{ van Genuchten parameters } \\
\hline & $\begin{array}{c}\alpha \\
\left(\mathrm{MPa}^{-1}\right)\end{array}$ & $\mathbf{m}$ & $\mathbf{n}$ & $\begin{array}{c}\theta \mathbf{r} \\
\left(\mathbf{c m}^{3} \mathbf{c m}^{-3}\right)\end{array}$ & $\begin{array}{c}\theta s \\
\left(\mathrm{~cm}^{3} \mathbf{c m}^{-3}\right)\end{array}$ \\
\hline \multicolumn{6}{|c|}{ Haplic Ferralsol (Arenic, Dystric, Ochric) } \\
\hline \multicolumn{6}{|c|}{1} \\
\hline $\mathrm{A}(0-12)$ & 0.151 & 0.294 & 1.417 & 0.031 & 0.351 \\
\hline Bw3 (150 - 208) & 0.026 & 0.380 & 1.613 & 0.050 & 0.341 \\
\hline \multicolumn{6}{|l|}{ - } \\
\hline$A(0-12)$ & 0.033 & 0.464 & 1.865 & 0.039 & 0.327 \\
\hline Bw3 (160 - 202) & 0.033 & 0.355 & 1.550 & 0.059 & 0.339 \\
\hline \multicolumn{6}{|c|}{3} \\
\hline $\mathrm{A}(0-13)$ & 0.029 & 0.608 & 2.002 & 0.041 & 0.332 \\
\hline Bw $(150-200)$ & 0.011 & 0.608 & 2.553 & 0.060 & 0.318 \\
\hline \multicolumn{6}{|c|}{$\begin{array}{c}\text { Dystric Rubic Siderolic Arenosol } \\
1\end{array}$} \\
\hline $\mathrm{A}(0-10)$ & 0.026 & 0.512 & 2.048 & 0.036 & 0.317 \\
\hline C4 (162 - 210) & 0.012 & 0.592 & 2.454 & 0.055 & 0.305 \\
\hline \multicolumn{6}{|c|}{2} \\
\hline $\mathrm{A}(0-11)$ & 0.069 & 0.447 & 1.810 & 0.054 & 0.381 \\
\hline C4 (150 - 206) & 0.105 & 0.305 & 1.440 & 0.037 & 0.399 \\
\hline \multicolumn{6}{|c|}{3} \\
\hline $\mathrm{A}(0-13)$ & 0.041 & 0.463 & 1.864 & 0.039 & 0.371 \\
\hline C4 (156 - 206) & 0.017 & 0.536 & 2.156 & 0.046 & 0.353 \\
\hline \multicolumn{6}{|c|}{$\begin{array}{l}\text { Dystric Chromic Siderolic Arenosol } \\
1\end{array}$} \\
\hline $\mathrm{A}(0-10)$ & 0.029 & 0.489 & 1.959 & 0.045 & 0.395 \\
\hline C5 $(176-211)$ & 0.017 & 0.588 & 2.427 & 0.042 & 0.369 \\
\hline \multicolumn{6}{|c|}{2} \\
\hline $\mathrm{A}(0-10)$ & 0.076 & 0.429 & 1.753 & 0.032 & 0.383 \\
\hline C4 (140 - 200) & 0.134 & 0.322 & 1.474 & 0.021 & 0.372 \\
\hline \multicolumn{6}{|c|}{3} \\
\hline $\mathrm{A}(0-10)$ & 0.208 & 0.259 & 1.349 & 0.030 & 0.360 \\
\hline C4 $(140-210)$ & 0.030 & 0.471 & 1.891 & 0.035 & 0.357 \\
\hline \multicolumn{6}{|l|}{ (1) } \\
\hline $\mathrm{A}(0-12)$ & 4.455 & 0.196 & 1.243 & 0.025 & 0.389 \\
\hline C4 (130 - 203) & 0.025 & 0.555 & 2.247 & 0.027 & 0.312 \\
\hline
\end{tabular}

$\alpha, \mathrm{m}, \mathrm{n}=$ empirical parameters of the van Genuchten equation $1(1980) ; \theta \mathrm{r}=$ residual volumetric water content; $\theta \mathrm{s}=$ saturated volumetric water.

sandy soils, through soil water retention curves fitted to the model of van Genuchten (1980), the parameter " $\mathrm{n}$ " assumed values higher than one 1.0, and remained between 1.4 and 2.5 in Ferralsols, and between 1.2 and 2.4 in Arenosols (TableIV). However, Barreto et al. (2011) observed a tendency of sandy soils to have retention curves with higher slope, reflecting a small variation of pore size, with higher values for the parameter "n".
The parameter " $\alpha$ " related to the soil water retention curve of the van Genuchten model (1980) is associated with the inflection point of the curve (air intake point). High values of this parameter indicate the inflection point (corresponding to the predominant pore diameter) in little negative potential values. This indicates the presence of larger pores, which drain the water under low tensions, as seen in the A horizon of the profile 


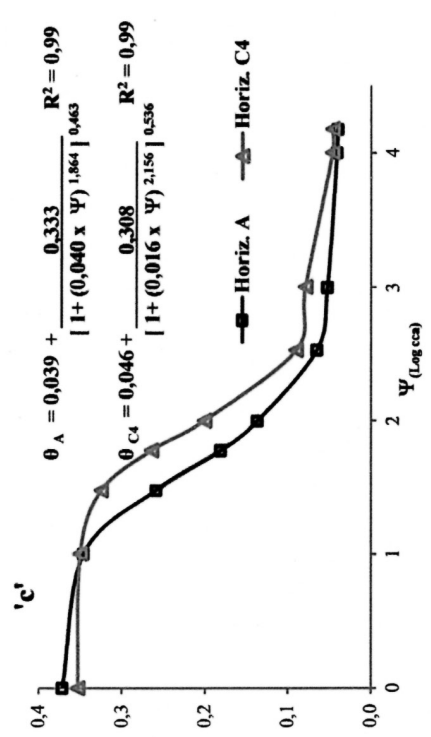

Dystric Chromic Siderolic Arenosol - 4 (Figure 4). The other results of the parameter " $\alpha$ " of the other water retention curves had relatively low values, between 0.01 and 0.13 (Table IV).

Indeed, the hydraulic behavior of the A horizon of Dystric Chromic Siderolic Arenosol - 4 is directly related to the pore-size distribution of this horizon, due to the amount of sand subfractions. In this profile, from the total sand content of 933 $\mathrm{g} \mathrm{kg}^{-1}, 18 \%$ is very coarse and coarse sand. Its macroporosity is $27 \%$ (Table II), representing $69 \%$ of its total porosity, which causes greater drainage at low tensions in its macropores.

For the other profiles, great variations were observed in the values of the parameter " $\alpha$ " (Table IV), not being possible to associate them with tendencies that defines the hydraulic characteristic of the soils.

In the sandy soils of the present study, the distribution of sand subfractions along the profile seems to explain the processes of water retention better than the clay fraction does, notwithstanding the fact that the small amounts of clay in these soils (between 40 and $150 \mathrm{~g} \mathrm{~kg}^{-1}$ ) have intensified their water retention capacity.

In order to characterize the hydraulic behavior of the sand subfractions and their contributions to water retention, the amounts of each pure sand subfraction (very coarse sand, coarse sand, medium sand, fine sand and very fine sand) were separated. Then, the water retention was determined and the SWRC was constructed for these subfractions, which are represented by Figure 5 .

As expected, coarser sand subfractions (very coarse and coarse) contributed more to the water drainage in the soil with low capacity of water retention, even at low tensions. This soil lost approximately $80 \%$ of the water from the pores when a tension of only $-1 \mathrm{kPa}(\cong 10 \mathrm{cwc} \cong 1.0 \log \mathrm{cwc})$ was applied, remaining with a volumetric moisture of $(\Theta) \cong 0.12 \mathrm{~cm}^{3} \mathrm{~cm}^{-3}$, because these particles have the arrangement that forms larger pores. 

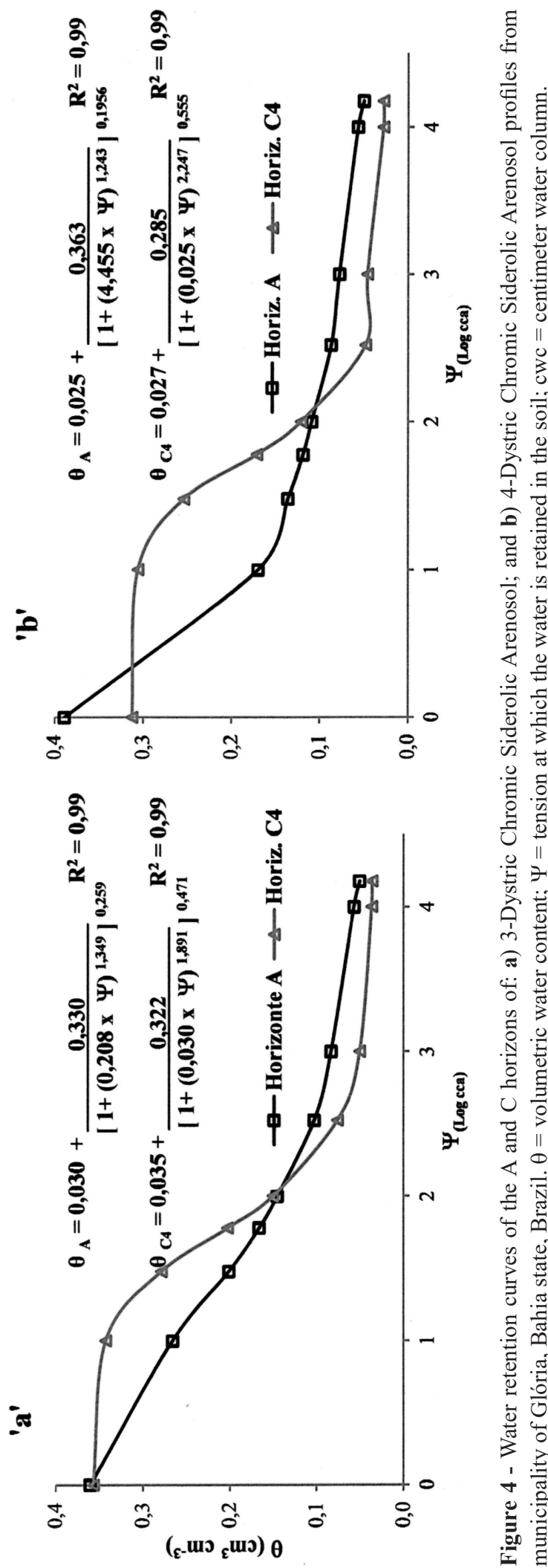

The sandy soils with greater quantities of sand in the range between fine and very fine sand present an arrangement that forms micropores, increasing their water retention capacity, as shown by the curves of fine sand and very fine sand (Figure 5). In this figure, the tests prove that even the medium sand has a higher water content in the field capacity $10 \mathrm{kPa}$, with volumetric moisture values of $(\Theta) \cong$ $0.12 \mathrm{~cm}^{3} \mathrm{~cm}^{-3}$, increasing to approximately $\cong 0.2$ $\mathrm{cm}^{3} \mathrm{~cm}^{-3}$ in the fine sands, and reaching $(\Theta) \cong 0.42$ $\mathrm{cm}^{3} \mathrm{~cm}^{-3}$ when only very fine sand is present.

Although the water retention curves of Figure 5 represent laboratory conditions, they can be extrapolated to the field situation, proving that the water characteristic of the sandy soils was closely related to the sizes of the sand particles, and that the water retention of these soils increases significantly when there is an increase of finer particles, in conjunction with silt and clay.

The subfractions of fine and very fine sand, having smaller diameters, allow greater surface area, increasing the water films between the particles and consequently leading to greater water retention (Kiehl 1979). These subfractions have water retention values about six times higher than those in very coarse and coarse sand (Table V). This illustrates the pronounced influence of the fine sand fraction on hydraulic phenomena, as well as its form of distribution of occurrence in the soil.

The subfractions very coarse and coarse sand have an arrangement in which the contact between particles is lower, resulting in larger pore sizes (Giménez et al. 1997) and, consequently, lower energy necessary to remove water (Hillel 1982). The water retention in the coarse sand fraction was very low compared with that of fine and very fine sand (Table V).

\section{FIELD CAPACITY, PERMANENT WILTING POINT AND AVAILABLE WATER}

Although there is not yet a consensus on the correct tension associated with field capacity for each 


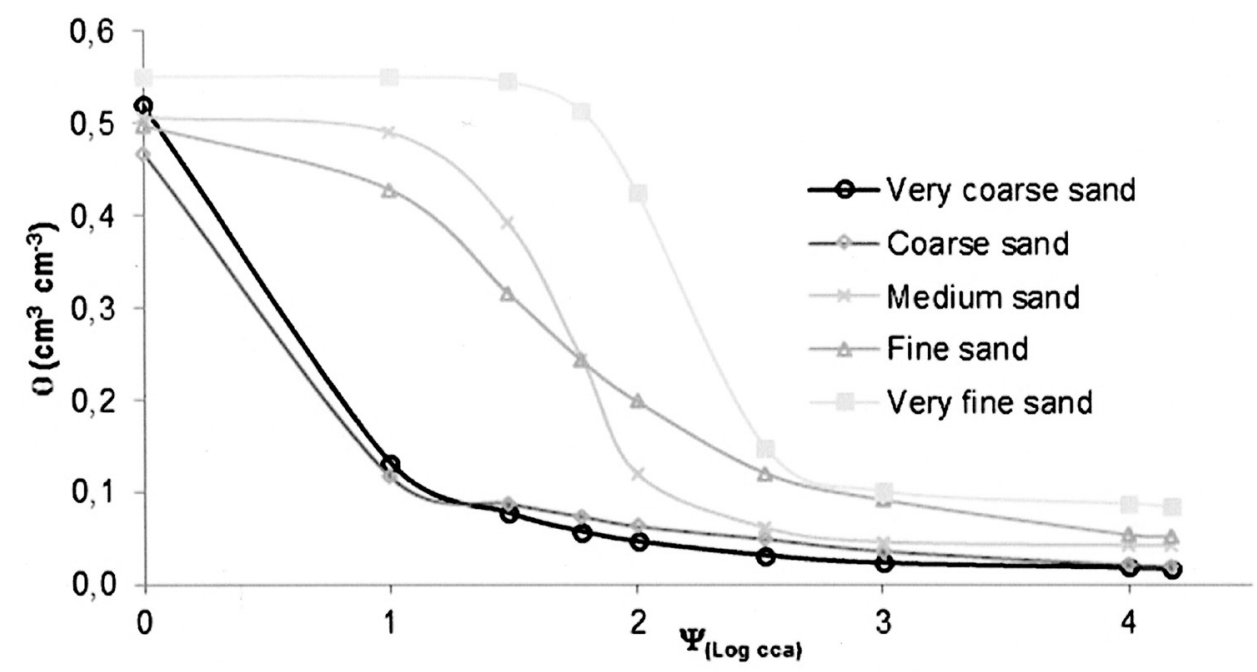

Figure 5 - Characteristics water retention curves in pure sand subfractions of sandy soils from the municipality of Glória, Bahia state, Brazil. $\theta=$ volumetric water content; $\Psi=$ applied tension; cwc $=$ centimeter water column.

soil type (Kirkham 2014), some authors consider tensions of $-10 \mathrm{kPa}$ for sandy soils and $-33 \mathrm{kPa}$ for soils with fine texture as corresponding to the field capacity (Bernardo et al. 2007).

The water contents at field capacity determined in situ ( $\mathrm{Fc}$ in situ) showed values lower than those determined in the laboratory, at the tension of 10 $\mathrm{kPa}$, but higher than those at $33 \mathrm{kPa}$, indicating that the tension at which the water is retained in these soils when they reach Fcin situ is between -10 and $-33 \mathrm{kPa}$ (Table VI). A similar result was reported by Jabro et al. (2009), who compared methods for the in situ determination of field capacity and observed values around $-18 \mathrm{kPa}$ for sandy soils. This proves that factors such as the distribution of sand fractions and their different pore sizes influence the energy of water retention in the soil and can show higher tensions when the soil reaches the equilibrium of the water content at field capacity.

According to the hydraulic parameters used for the calculation of the available water (AW), the great influence of size distribution of sand particles, forming different types of pores (macro, meso and micro), besides the influence of the other fractions (silt + clay), contributed to a different water retention behavior and to the tensions of water contents at Fc and Pwp in the studied soils (Table VI).

There was an increment in the retained water content from -33 to $-10 \mathrm{kPa}$. On average, the following results were obtained in \% volume: at the tension of $10 \mathrm{kPa}$, Ferralsols showed mean values of $13.6 \%$ in the surface horizon and $20.3 \%$ in the subsurface horizon; in Arenosols, the mean values were around $13.0 \%$ in the surface horizon and $16.0 \%$ in the subsurface horizon (Table VI).

As to the data of volumetric water content $(\theta)$, at the tension of $33 \mathrm{kPa}$, Ferralsols showed mean values of $7.6 \%$ in the surface horizon and $12.0 \%$ in the subsurface horizon. Arenosols showed mean values of $7.4 \%$ in the surface horizon and $7.7 \%$ in the subsurface horizon. Therefore, Ferralsols showed higher mean values of water retention in both horizons than Arenosols. These mean values were slightly higher than those observed in many studies conducted in the same region, in the municipality of Glória, Bahia state (CHESF 1987, 1989a, b, 1991, 1994), in which the field capacity (Fc) values of Arenosols were 6.3 to $7.5 \%$ by volume. The field capacity for sandy soils usually ranges from 10 to $20 \%$ in volume and, for clayey soils, from 35 to 50\% (Townsend 1972). 
TABLE V

Water retention values of the pure sand fraction at 10, 33, 100, 1,000 and $1,500 \mathrm{kPa}$ tensions, of sandy soils from the municipality of Glória, Bahia state, Brazil.

\begin{tabular}{|c|c|c|c|c|c|c|c|}
\hline \multirow{2}{*}{$\begin{array}{c}\text { Pure sand fraction } \\
\text { sample }\end{array}$} & \multicolumn{5}{|c|}{ Tension (- kPa) } & \multicolumn{2}{|c|}{ AW } \\
\hline & 10 & 33 & 100 & 1,000 & 1,500 & 1 & 2 \\
\hline & \multicolumn{7}{|c|}{$(\%)$} \\
\hline Very coarse sand & 4.66 & 3.14 & 2.31 & 1.80 & 1.66 & 3.0 & 1.48 \\
\hline Coarse sand & 6.23 & 4.85 & 3.68 & 1.88 & 1.85 & 4.38 & 3.00 \\
\hline Medium sand & 11.89 & 8.26 & 6.51 & 2.86 & 2.80 & 5.06 & 3.05 \\
\hline Fine sand & 19.77 & 11.98 & 9.09 & 5.15 & 5.11 & 14.66 & 6.87 \\
\hline Very fine sand & 42.50 & 14.78 & 11.74 & 8.69 & 8.43 & 34.07 & 6.35 \\
\hline
\end{tabular}

Observation: $\mathrm{AW}=$ Available water; $\mathrm{AW} 1=(\mathrm{Fc}-\mathrm{Pwp}), \mathrm{Fc}$ at tension of $10 \mathrm{kPa}$; AW2 $=(\mathrm{Fc}-\mathrm{Pwp}), \mathrm{Fc}$ at tension of $33 \mathrm{kPa} . \mathrm{Fc}=$ Field capacity; Pwp = Permanent wilting point.

TABLE VI

Available water, field capacity and permanent wilting point of sandy soils from the municipality of Glória, Bahia state, Brazil.

\begin{tabular}{|c|c|c|c|c|c|c|c|}
\hline \multirow{4}{*}{ Horizon } & \multicolumn{3}{|c|}{ Field capacity - Fc } & \multirow{3}{*}{$\begin{array}{c}\text { Pwp } \\
-1,500 \mathrm{kPa}\end{array}$} & \multicolumn{3}{|c|}{ Available water - AW } \\
\hline & \multirow{2}{*}{ In situ } & \multicolumn{2}{|c|}{ Laboratory } & & \multirow{2}{*}{$\begin{array}{c}\text { In situ } \\
\text { AW1 }\end{array}$} & \multicolumn{2}{|c|}{ Laboratory } \\
\hline & & $-10 \mathrm{kPa}$ & $-33 \mathrm{kPa}$ & & & AW2 & AW3 \\
\hline & \multicolumn{7}{|c|}{-------------------------------------------------- 0} \\
\hline \multirow{2}{*}{\multicolumn{8}{|c|}{ Haplic Ferralsols (Arenic, Dystric, Ochric) }} \\
\hline & & & & & & & \\
\hline A & & 13.36 & 9.43 & 4.31 & 6.14 & 9.06 & 5.13 \\
\hline Bw3 & 14.15 & 21.02 & 14.73 & \multirow[t]{2}{*}{7.46} & 6.69 & 13.56 & 7.27 \\
\hline & & & & & & & \\
\hline A & 10.41 & 13.58 & 7.03 & 3.78 & 6.63 & 9.81 & 3.25 \\
\hline Bw3 & 14.28 & 19.91 & 12.93 & 6.85 & 7.43 & 13.06 & 6.08 \\
\hline \multicolumn{8}{|c|}{10.00} \\
\hline A & 9.79 & 13.84 & 6.39 & 3.40 & 6.39 & 10.44 & 2.99 \\
\hline $\mathrm{Bw}$ & 14.38 & 19.89 & 10.53 & 5.27 & 9.11 & 14.63 & 5.27 \\
\hline \multicolumn{8}{|c|}{ Dystric Rubic Siderolic Arenosols } \\
\hline \multicolumn{8}{|c|}{1} \\
\hline A & 9.31 & 12.94 & 5.45 & 2.77 & 6.54 & 10.17 & 2.68 \\
\hline $\mathrm{C} 4$ & 12.16 & 19.45 & 10.68 & 5.33 & 6.84 & 14.12 & 5.35 \\
\hline \multicolumn{8}{|c|}{2} \\
\hline A & 10.59 & 12.19 & 7.79 & 5.15 & 5.45 & 7.04 & 2.65 \\
\hline $\mathrm{C} 4$ & 12.38 & 16.37 & 11.60 & 4.93 & 7.45 & 11.44 & 6.66 \\
\hline \multicolumn{8}{|c|}{12.00} \\
\hline A & 9.41 & 13.63 & 6.49 & 3.42 & 5.99 & 10.21 & 3.07 \\
\hline $\mathrm{C} 4$ & 12.78 & 20.09 & 7.90 & 4.45 & 8.33 & 15.64 & 3.45 \\
\hline \multicolumn{8}{|c|}{ Dystric Chromic Siderolic Arenosols } \\
\hline \multicolumn{8}{|c|}{1} \\
\hline A & 11.18 & 16.53 & 8.07 & 4.09 & 7.09 & 12.44 & 3.98 \\
\hline C5 & 11.37 & 17.37 & 8.41 & 4.02 & 7.35 & 13.35 & 4.39 \\
\hline \multicolumn{8}{|c|}{17.0} \\
\hline A & 8.58 & 10.74 & 6.21 & 3.11 & 5.47 & 7.63 & 3.10 \\
\hline $\mathrm{C} 4$ & 9.83 & 12.31 & 7.69 & 3.00 & 6.83 & 9.32 & 4.69 \\
\hline \multicolumn{8}{|c|}{3} \\
\hline $\mathrm{A}$ & 9.23 & 14.50 & 10.26 & 4.64 & 4.59 & 9.85 & 5.62 \\
\hline $\mathrm{C} 4$ & 10.24 & 15.08 & 7.21 & 3.34 & 6.90 & 11.74 & 3.88 \\
\hline \multicolumn{8}{|c|}{4} \\
\hline $\mathrm{A}$ & 8.54 & 11.03 & 7.87 & 3.69 & 4.12 & 6.61 & 3.45 \\
\hline $\mathrm{C} 4$ & 7.84 & 11.42 & 4.30 & 2.32 & 5.52 & 9.09 & 1.98 \\
\hline
\end{tabular}

Pwp $=$ Permanent wilting point; AW1 $=\mathrm{Fc}_{\mathrm{in} \mathrm{situ}}-\mathrm{Pwp}$; AW2 $=\mathrm{Fc}_{10 \mathrm{kPa}}-\mathrm{Pwp} ; \mathrm{AW} 3=\mathrm{Fc}_{33 \mathrm{kPa}}-\mathrm{Pwp}$. 
These differences in water retention of sandy soils occurred because of the influence of the predominance of fine sand (Franzmeier et al. 1960, Rivers and Shipp 1978, Silva et al. 2006) or the combined effect of finer sand and silt + clay (Muggler et al. 1996), especially in those soils with very low silt and clay contents, or the different arrangement or packing of soil particles (Oliveira et al. 2000, Resende and Rezende 1983) or the constituent material (Machado et al. 2008). These facts favor a greater water retention, resulting in higher availability of water to plants.

\section{CONCLUSIONS}

The distribution of the granulometric fractions, with higher amounts of fine and medium sand fractions, and pore size-distribution with higher proportions of micropores, of the sandy soils of the semiarid region in Northeast of Brazil, influenced the retention and availability of water, with Ferralsols having higher water retention capacity than Arenosols.

The characteristics of the soil water retention curves were influenced by the higher proportion of micropores, related to the total porosity, with Ferralsols presenting values averaging more than $63 \%$ and Arenosols more than 54\%, resulting in high water retention of these soils at a range of lower potential between the field capacity and the permanent wilting point.

Higher amounts of fine and medium sand fractions of Ferralsols and Arenosols have an important role in their water retention process. Although low, clay contents between 50 and 150 $\mathrm{g} \mathrm{kg}^{-1}$ also contribute to the soil water retention capacity which is directly reflected by soil water retention curves.

\section{ACKNOWLEDGMENTS}

We thank Instituto de Pesquisa Agropecuário de Pernambuco (IPA) and Laboratório de Física do
Solo of Universidade Federal Rural de Pernambuco for their help in the soil laboratory analysis. We also thank Embrapa Solos UEP/Recife for the one-year scholarship of the first author; Conselho Nacional de Desenvolvimento Científico e Tecnológico (CNPq) for the researcher grant of the second and fifth authors and Prof. Charles Allan Jones and Prof. Raghaven Srinivasan from Texas A\&M Universiy for providing language help. This research did not receive any specific grant from funding agencies in the public, commercial, or not-for-profit sectors.

\section{AUTHOR CONTRIBUTIONS}

Conceptualization: Roberto da Boa Viagem Parahyba, Maria do Socorro Bezerra de Araújo, and Brivaldo Gomes de Almeida. Methodology: Roberto da Boa Viagem Parahyba and Brivaldo Gomes de Almeida. Validation: Brivaldo Gomes de Almeida, Fernando Cartaxo Rolim Neto, Everardo Valadares de Sá Barreto Sampaio, and Anildo Monteiro Caldas. Formal Analysis: Brivaldo Gomes de Almeida, Maria do Socorro Bezerra de Araújo, Fernando Cartaxo Rolim Neto, and Anildo Monteiro Caldas. Investigation: Roberto da Boa Viagem Parahyba. Data Curation: Roberto da Boa Viagem Parahyba. Writing - Original Draft: Roberto da Boa Viagem Parahyba. Writing Review and Editing: Brivaldo Gomes de Almeida, Maria do Socorro Bezerra de Araújo, Roberto da Boa Viagem Parahyba, Fernando Cartaxo Rolim Neto, Everardo Valadares de Sá Barreto Sampaio, and Anildo Monteiro Caldas. Visualization: Fernando Cartaxo Rolim Neto, Everardo Valadares de Sá Barreto Sampaio, and Anildo Monteiro Caldas. Supervision: Maria do Socorro Bezerra de Araújo. Project Administration: Maria do Socorro Bezerra de Araújo and Brivaldo Gomes de Almeida. Funding Acquisition: Roberto da Boa Viagem Parahyba and Brivaldo Gomes de Almeida. 


\section{REFERENCES}

ABRAHÃO WAP, COSTA JWV, MELLO JWV AND NEVES JCL. 1998. Distribuição de frequência de tamanho da fração areia e compacidade relativa de solos desenvolvidos de sedimentos do grupo geológico Barreiras. R Bras Cienc Solo 22: 1-9.

ARAÚJO SMS. 2011. A região semiárida do Nordeste do Brasil: Questões ambientais e possibilidades de uso sustentável dos recursos. RIOS Eletrônica, Revista Científica da Faculdade Sete de Setembro, FASETE. Ano 5, n. 5, p. 89-98.

BARRETO HBF, BATISTA RO, FREIRE FGC, SANTOS WO AND COSTA FGB. 2011. Análises de indicadores de retenção e armazenamento de água no solo do perímetro irrigado de Gorutuba, em Janaúba, Minas Gerais. Rev Verde Agroecol Desenvolv Sustent 6(5): 189-192.

BERNARDO S, SOARES AA AND MANTOVANI EC. 2007. Manual de irrigação, $8^{\mathrm{a}}$ ed., Viçosa, Minas Gerais: Universidade Federal de Viçosa, 625 p.

BOUMA J. 1991. Influence of soil macroporosity on environmental quality. Adv Agron 46: 1-37.

BRUAND A, HARTMANN C AND LESTURGEZ G. 2005. Physical properties of tropical sandy soils: A large range of behaviours, In: Symposium International On The Management Of Tropical Sandy Soils For Sustainable Agriculture: A holistic approach for sustainable development of problem soils in the tropics. Khon Kaen, Thailand. Proceeding. Khon Kaen, FAO, 2005. p. 148158. http://www.fao.org/docrep/010/ag125e/ag125e00. htm (Accessed 21.06.2018).

CAMARGO AO AND ALLEONI LRF. 1997. Compactação do solo e o desenvolvimento das plantas, $1^{\text {a }}$ ed., Piracicaba: Escola Superior de Agricultura Luiz de Queiroz/USP, 132 p.

CASSEL DK AND NIELSEN DR. 1986. Field Capacity and Available Water Capacity, In: Klute A (Ed), Methods of Soil Analysis: Part 1-Physical and Mineralogical Methods. Soil Science Society of American, Book Series 5.1, Madison: Soil Science Society of America, American Society of Agronomy, p. 901-926.

CASTRO AL AND PANDOLFELLI VC. 2009. Revisão: Conceitos de dispersão e empacotamento de partículas para a produção de concretos especiais aplicados na construção civil. Cerâmica 55: 18-32.

CHESF - COMPANHIA HIDRO ELÉTRICA DO SÃO FRANCISCO. 1987. Projeto de ocupação da borda do lago de Itaparica, margem esquerda. Relatório de Pedologia. Recife, Pernambuco. Tomos 1, 2 e 3. (Relatório Técnico Themag Engenharia/Chesf). 695 p.

CHESF - COMPANHIA HIDRO ELÉTRICA DO SÃO FRANCISCO. 1989a. Relatório Final. Disponibilidade de água de solos das áreas de Glória e Rodelas - Bahia, do Projeto do Lago, Bahia. Hydroservice Engenharia e Planejamento Ltda, Recife, Pernambuco. Tomo 2 e 3, v.15. Anexo 11, 174 p.

CHESF - COMPANHIA HIDRO ELÉTRICA DO SÃO FRANCISCO. 1989b. Reassentamento da População do Lago de Itaparica. Projeto Apolônio Sales. Levantamento Ultradetalhado de solos. Descrição das prospecções, testes hidropedológicos e Boletins de análise, v.3, Projetec, Recife, Pernambuco, 380 p.

CHESF - COMPANHIA HIDRO ELÉTRICA DO SÃO FRANCISCO. 1991. Relatório Final. Projeto de irrigação Pedra Branca. Levantamentos de solos e classes de terra para irrigação. HYDROS Engenharia e Planejamento Ltda, Salvador, Bahia. Tomo 2 e 3, v.15. Anexo 1l, 114 p.

CHESF - COMPANHIA HIDRO ELÉTRICA DO SÃO FRANCISCO. 1994. Levantamento pedológico complementar do projeto jusante, Município de GlóriaBA. Recife: CHESF. 86 p.

CORREIA RC, KILL LHP, MOURA MSB, CUNHA TJF, JESUS JUNIOR LA AND ARAÚJO JLP. 2011. A região semiárida brasileira. In: Voltolini TV (Ed), Produção de caprinos e ovinos no Semiárido. Petrolina, PE: Embrapa Semiárido, Cap. 1, p. 21-48.

CUNHA P, MARQUES JUNIOR J, CURI N, PEREIRA GT AND LEPSCH IF. 2005. Superfícies geomórficas e atributos de Latossolos em uma sequência areníticobasáltica da região de Jaboticabal (SP). Rev Bras Cienc Solo 29: 81-90.

DEEPAGODA TKKC, MOLDRUP P, SCHJØNNING P, DE JONGE LW, KAWAMOTO K AND KOMATSU T. 2011. Density-corrected models for gas diffusivity and air permeability in unsaturated soil. Vadose Zone J 10: 226238.

DEXTER AR. 2004. Soil physical quality: Part I. Theory, effects of soil texture, density, and organic matter, and effects on root growth. Geoderma 12: 201-214.

DONAGEMMA GK ET AL. 2016. Caracterização, potencial agrícola e perspectivas de manejo de solos leves no Brasil. Pesq Agropec Bras 51: 1003-1020.

FERREIRA MM. 2010. Caracterização física do solo. In: Lier QJ (Ed), Física do Solo. Viçosa: Sociedade Brasileira de Ciência do Solo, p. 1-27.

FIDALSKI J, TORMENA CA, ALVES SJ AND AULER PAM. 2013. Influência das frações de areia na retenção e disponibilidade de água em solos das formações Caiuá e Paranavaí. R Bras Ci Solo 37: 613-621.

FILIZOLA HF, FONTANA A, DONAGEMMA GK, SOUZA MD, BORTOLON SO AND BORTOLON L. 2017. Qualidade física de solos influenciada pelo uso e manejo na região de Guaraí, TO. Jaguariúna, São Paulo: Embrapa Meio Ambiente, 34 p. (Boletim de Pesquisa e Desenvolvimento/Embrapa Meio Ambiente, ISSN 1516$4675 ; 72)$. 
FRANZMEIER DP, WHITSIDE EP AND ERICSON AE. 1960. Relationship of texture classes of fine earth to readily available water. Trans Intern Congr Soil Sci $7^{\text {th }} 1: 354-363$.

GENRO JUNIOR SA, REINERT DJ, REICHERT JM AND ALBUQUERQUE JA. 2009. Atributos físicos de um Latossolo Vermelho e produtividade de culturas cultivadas em sucessão e rotação. Cienc Rural 39(1): 65-73.

GIMÉNEZ D, PERFECT E, RAWLS WJ AND PACHEPSKY YA. 1997. Fractal Models for Predicting Soil Hydraulic Properties: A Review. Engineering Geology 48: 161-183.

HILLEL D. 1982. Introduction to Soil Physics, $1^{\text {st }}$ ed., San Diego: Academic Press, 264 p.

HILLEL D. 1998. Environmental soil physics, $1^{\text {st }}$ ed., San Diego: Academic Press, 771 p.

HILLEL D. 2003. Introduction to environmental soil physics, $1^{\text {st }}$ ed., New York: Academic Press, 494 p.

IUSS WORKING GROUP WRB. 2014. World Reference Base for Soil Resources. 2014. International soil classification system for naming soils and creating legends for soil maps. World Soil Resources Reports, n. 106. FAO, Rome. http:// www.fao.org/3/a-i3794e.pdf. (Accessed 15.08.2015).

JABRO JD, EVANS RG, KIM Y AND IVERSEN WM. 2009. Estimating in situ soil-water retention and field water capacity in two contrasting soil textures. Irrig Sci 27: 223229.

KER JC. 1997. Latossolos do Brasil: uma revisão. Geonomos 5: $17-40$.

KIEHL EJ. 1979. Manual de edafologia: Relações Solo Planta, $1^{\text {a }}$ ed., São Paulo: Agronômica Ceres, 262 p.

KLEIN VA, BASEGGIO M, MADALOSSO T AND MARCOLIN CD. 2010 Textura do solo e a estimative do teor de água no ponto de murcha permanente com psicômetro. Ciência Rural 40(7): 1550-1556.

KIRKHAM MB. 2014. Principles of Soil and Plant Water Relations, 2nd. Edition. Boston: Elsevier Academic Press, $598 \mathrm{p}$.

KOHNKE H. 1968. Soil physics, $1^{\text {st }}$ ed., New York: McGrawHill, 224 p.

LIBARDI PL. 2010. Água no solo. In: Lier QJV (Ed), Física do solo. Viçosa: Sociedade Brasileira de Ciência do Solo, p. 103-152.

MACHADO JL, TORMENA CA, FIDALSKI J AND SCAPIM CA. 2008. Inter-relações entre as propriedades físicas e os coeficientes da curva de retenção de água de um Latossolo sob diferentes sistemas de uso. R Bras Ci Solo 32: 495-502.

MANFREDINI S, PADOVESE PP AND OLIVEIRA JB. 1984. Efeito da composição granulometria da fração área no comportamento hídrico de Latossolos de textura média e Areias Quartzosas. R Bras Ci Solo 8: 13-16.

MECKE M, WESTMAN CJ AND ILVESNIEMI H. 2002. Water retention capacity in coarse Podzol profiles predicted from measured soil properties. Soil Sci Soc Am J 66: 1-11.
MOSADDEGHI MR, KOOLEN AJ, HAJABBASI MA, HEMMAT A AND KELLER T. 2007. Suitability of precompression stress as the real critical stress of unsaturated agricultural soils. Biosyst Eng 98: 90-101.

MOTA JCA, LIBARD PL, BRITO AS, ASSIS JUNIOR RN AND AMARO FILHO J. 2010. Armazenagem de água e produtividade de meloeiro irrigado por gotejamento, com a superfície do solo com cobertura e desnuda. R Bras Ci Solo 34: 1721-1731.

MUALEM Y. 1976. A new model predicting the hydraulic conductivity of unsaturated porous media. Water Resour Res 12: 513-522.

MUGGLER CC, CURI N, SILVA LN AND LIMA JM. 1996. Características pedológicas de ambientes agrícolas nos Chapadões do Rio Corrente, Sudeste da Bahia. Pesq Agropec Bras 31: 221-231.

OLIVEIRA IR, STUDART AR, PILEGGI RG AND PANDOLFELLI VC, 2000. Dispersão e empacotamento de partículas: princípios básicos e aplicações em processamento cerâmico, $1^{\mathrm{a}}$ ed., São Paulo: Fazendo Arte, $224 \mathrm{p}$.

OLIVEIRA NETO MB, SANTOS JCP, ARAÚJO FILHO JC, PARAHYBA RBV, LEITE AP, RIBEIRO FILHO MRR AND GOMES EC. 2007. Mapeamento dos solos, In: Araújo Filho JC, Santos JC and Luz LRQP(Eds), Avaliação Detalhada do Potencial de Terras para irrigação nas Áreas de Reassentamento de Colonos do Projeto Jusante GlóriaBA. Embrapa Solos UEP/NE, Recife, p. 23-54.

OR D AND WRAITH JM. 2002. Soil water content and water potential relationships. In: Warrick AW (Ed), Soil physics companion. Boca Raton: CRC Press, p. 49-84.

PREVEDELLO CL. 1996. Física do solo com problemas resolvidos, $1^{\mathrm{a}}$ ed., Curitiba: Saleswand-Discovery, $446 \mathrm{p}$.

REEVE JM AND CARTER AD. 1991. Water release characteristics. In: Smith KA and Mullins CE (Eds), Soil analysis: Physical methods. New York, M. Dekker, p. 111160.

REICHARDT K. 1990. A água em sistemas agrícolas, $1^{\text {a }}$ ed., São Paulo: Manole Ltda, Cap. 3, p. 27-65.

REICHARDT K AND TIMM LC. 2004. Solo, planta e atmosfera: conceitos, processos e aplicações, $1^{\text {a }}$ ed., Piracicaba: Manole Ltda, 478 p.

REINERT DJ AND REICHERT JM. 2006. Coluna de areia para medir a retenção de água no solo: protótipos e teste. Ciência Rural 36(6): 1931-1935.

RESENDE M AND REZENDE SB. 1983. Levantamento de solos: uma estratificação de ambientes. Informe Agropecuário, Belo Horizonte v. 9, n. 109, p. 3-25.

RIBEIRO KD, MENEZES SM, MESQUITA MGB AND SAMPAIO FMT. 2007. Propriedades físicas do solo influenciadas pela distribuição de poros, de seis classes de solos da região de Lavras - MG. Cienc Agrotec 31(4): $1167-1175$. 
RICHARDS LA. 1947. Pressure-membrane apparatus, construction and use. Agro Eng Madison 28: 241-247.

RIDGWAY K AND TARBUCK KJ. 1968. Particulate mixture bulk densities. Chem Process Eng 49(2): 103-105.

RIVA RDD. 2010. Efeitos das propriedades físicas dos grãos da fração areia de solos arenosos e de agentes cimentação no comportamento de sistemas empacotados. Viçosa, MG. 2010. 157 p. Tese de Doutorado em Engenharia Civil. Universidade Federal de Viçosa. Viçosa, Minas Gerais.

RIVERS ED AND SHIPP RF. 1972. Available water capacity of sandy and gravelly North Dakota soils. Soil Sci 113: 74-80.

RIVERS ED AND SHIPP RF. 1978. Soil water retention as related to particle size selected sand and loamy sands. Soil Sci 126: 94-100.

SCHIOAVO JA, PEREIRA MG, MIRANDA LPM, DIAS NETO AH AND FONTANA A. 2010. Caracterização e classificação de solos desenvolvidos de arenitos da formação Aquidauana - MS. R Bras Ci Solo 34: 881-889.

SILVA AP, IMHOFF S AND KAY B. 2004. Plant response to mechanical resistance and air-filled porosity of soils under conventional and no-tillage system. Sci Agric 61: 451-456.

SILVA EM, LIMA JEFW, AZEVEDO JA AND RODRIGUES LN. 2006. Valores de tensão na determinação da curva de retenção de água de solos do Cerrado. Pesq Agropec Bras 41: 323-330.

SILVA AP, TORMENA CA, DIAS JUNIOR MS, IMHOFF S AND KLEIN VA. 2010. Indicadores da qualidade física do solo. In: Van Lier QJ (Ed), Física do Solo. Viçosa:
Sociedade Brasileira de Ciência do Solo, Viçosa, Mina Gerais, p. 241-281.

SIQUEIRA OJW. 2007. Diagnóstico da fertilidade dos solos do estado de Sergipe, In: Sobral LF, Viegas PRAV, Siqueira OJW, Anjos JL, Barreto MCV and Gomes JBV (Eds), Recomendações para o uso de corretivos e fertilizantes no estado do Sergipe, Aracaju: Embrapa Tabuleiros Costeiros, Aracaju, p. 39-70.

SOIL SCIENCE DIVISION STAFF. 2017. Soil survey manual. In: Ditzler C, Scheffe K and Monger HC (Eds), Handbook 18. USDA, Washington, D.C, Government Printing Office, $603 \mathrm{p}$.

TAYLOR SA AND ASCHROFT GL. 1972. Physical edaphology. The physics of irrigated and nonirrigated soils, $1^{\text {st }}$ ed., San Francisco: Freeman WH, 533 p.

TEXEIRA PC, DONAGEMMA GK, FONTANA A AND TEIXEIRA WG. 2017. Manual de métodos de análise de solos, Técnicos, $3^{\mathrm{a}}$ ed., Brasília, DF: Embrapa, 574 p.

TOWNSEND WN. 1972 An introduction to the scientific study of the soil, $5^{\text {th }}$ ed., London. Edward Arnold, 209 p.

VAN GENUCHTEN MT. 1980. A closed-form equation for predicting the hydraulic conductivity of unsaturated soils. Soil Sci Soc Am J 44: 892-898.

VAN GENUCHTEN MT, LEIJ FJ AND YATES SR. 1994. The RETC code for quantifying the hydraulic functions of unsaturated soils: version 1.1 Riverside: USDA, U. S. Salinity Laboratory, ARS, 1994. Disponível: <http://www. epa.gov/ada/csmos/models/retc.html $>$.

WEIL RR AND BRADY NC. 2016. The nature and properties of soils, $15^{\text {th }}$ ed., Columbus: Pearson Education, 1086 p. 